\title{
Reclamation of the Narrative for the Silenced Voice in Margaret Atwood's The Penelopiad
}

\author{
--Saroj G.C. \\ Teaches English, \\ Nepal Open University, Manbhawan, \\ Lalitpur, Nepal. \\ Email: sarojgc1@gmail.com
}

https://doi.org/10.3126/litstud.v34i01.39538

\section{Abstract}

This article analyzes Margaret Atwood's The Penelopiad, a rewriting of Homeric epic, The Odyssey. Atwood rewrites the story - the saga of gallantry and triumphalism of Odysseus, with narrative shift that brings postmodern irony and parody, self-reflexivity and metafiction, and intertextuality and paratextuality into play. The article tries explore if Atwood's shifting of narrative orientation of the Homeric epic yields any different and substantial reception and interpretation of the epic in the recent context.Moreover, I demonstrate how Atwood's reconstruction and subsequently the empowerment of the minor characters unfolds the incompatibilities and discrepancies the official version of Homer's epic, and brings the marginal voice to the front by granting a variety of narrative access.I argue, giving subject positions to silent agents and using various genres of expression, for instance, history and myth, Atwood, through the deployment of an autodiegetic narrative, brings together gender, genre and language in such a way that results in a decisive shift in conceptualizing the narrative structure for the marginal voice and agency female characters. The article concludes that why rereading of classical and canonical text is crucial to bring the marginals' claim to a subject position, and produce a different language and literature that allows space for expression subjectivity of characters on the margins.

Keywords: Metafiction, Point of View, Myth, Historiography, Marginal Voice, Irony, Parody

\section{Re-contextualizing the Reception of Myth}

Atwood begins Penelope's story with the line: "Now that I'm dead I know everything" (Atwood 1). The narrator is dead, languishing in Hades, the underworld, and, paradoxically, she knows everything, and enjoys the liberty of telling and "knowing" everything which was not possible when she was alive, and when she was a treated as a token in the Homer's epic. Now, she has decided to tell everyone her version of the story. She is in grave, and grave, where no worldly rules exist, symbolizes an abode of absolute freedom. The dead Penelope does not have to be regulated any patriarchal conventions and restrictions. This is the place where traditional 
and patriarchal structure lays no hands. She has to tell her story because "many people have believed that his [Odysseus'] version of the events was the true one, and she is cognizant of the legends that cascaded through the "official version" (Atwood 2). In the very outset of the text, Atwood succinctly points out the incredulity toward the official version and the urgency of retelling the myth in modern context, for "The story as told in The Odyssey doesn't hold water: there are too many inconsistencies" (Atwood Xv).

This shift in the narrative point of view foregrounds Atwood's conflict with the heroic codes and the patriarchal nature of the Homeric text, and recreates the stories of Penelope and of her twelve maids who were hanged under Odysseus' orders. In fact, Atwood's version of The Odyssey switches between prose narration- the reminiscences by Penelope Hades and other forms of writing that convey the voices of the twelve maids. By giving voice to Penelope as an autodiegetic narrator, and to the chorus of maids who comment on the queen's narrative, Atwood brings a paradigm shift in the perception and orientation of the events and their meaning. The intention of Atwood is clear:

The maids form a . . Chorus which focuses on two questions which must pose themselves after any close reading of The Odyssey: what led to the hanging of the maids, and what was Penelope really up to? The story in The Odyssey doesn't hold water: there are too many inconsistencies. I've always been haunted by the maids and, in The Penelopiad, so is Penelope herself. (Atwood $\mathrm{XV}$ )

However, critical scholarship on Atwood has paid minimal attempts in scrutinizing narrative feats, subtle and profound in their functions though Margaret Atwood's The Penelopiad received a substantial engagement and received manifold of critical voices. Most of them focus on her venture of retelling the Homerian The Odyssey, a closed, canonical and well-received text and considered also as a timeless and eternal human creation (Howells 62). For a start, Howells observes that Atwood's retelling of Homeric myth is "herstory" for modern readers, and therefore she significantly, "shifts the focus of The Odyssey away from grand narratives of war, relocating it in the micronarratives of women at home" (63). In similar line, Hauser suggests that the novella goes beyond the classical reception and tells "another story" as Atwood "deliberately undermines Penelope's self-presentation as a faithful wife and benevolent queen through the rupturing of Penelope's voice and the alternation of Penelope's tale with the testimony of the maids she had killed" (24). However, Jung focuses on democratization of the text has 
slacken the tradition of western literary tradition by making it as a crossroad of genres (42). Finally, Kapuscinski argues that Atwood's rewriting of the myth(s) "demonstrate[s] the enduring relevance of myth and its utility in providing readers with a means to explore and critique the effectiveness of judicial responses to the violent acts of women, thus offering a place where literature and broader human rights issues meet" (42).

This article mainly scrutinizes Atwood's use of narrative point of view, parody and irony, intertextuality, historiographic metafiction elements. The structure, roles and space in the narrative are the major arena of analysis to demonstrate how Atwood tries retells the stereotyped Penelope myth and capitalizes on them. I argue that Atwood, writing against the grain, presents the same Penelope in a nuanced and sarcastic way that demystifies the myth - the saga of gallantry and trium-phalism ${ }^{l}$ - as its very fabric of the myth. Specifically, the article has two-fold objectives: I argue that how this clever reproduction of the myth brought by alteration in narration gives a different point of view in the story that ultimately constitute unique identity of the silenced female characters; second, my discussion shows that the present unique narrative form, a constitutive of different texts, registers a strong complaint against the stereotypical representation of the mythic culture.

\section{The Voice from the Grave}

The Odyssey is a linear storytelling by a heterodiegetic narrator, and tells a monolithic, singular and unequivocal story line. A recitation of a blind poet, who recounts the stories, told by a famous liar and adventurer, the poem contains narrative within narrative. The epic begins with the Goddess Athena relating to her father the story of Odysseus' troubles getting home from the siege at Troy. Telemachus leaves Ithaca in search of news of his father, and is diverted by the stories of Nestor and of Menelaus, about their own exploits, those of Odysseus as well as the other heroes of the Trojan War. Odysseus narrates his wanderings to a fascinating Phaecian court. Even in the Underworld, Anticleia tells Odysseus the story of his besieged wife, left back home. In the Greek epics, women do not star in their own tales so much as play supporting roles in the adventures of others (Collins 62-3).

In contrast, Atwood's introspective and self-reflexive narrator, Penelope, reverses obverse narrative structure of Odyssey. Now, the

\footnotetext{
${ }^{1}$ Odysseus' bravery is substantially described on masculine features. That is to say, the praise is more phallus-centric. Here, the term "triumphalism" has been defamiliarized to refer to victory and gallantry that alludes more to phallus. See, Meaning of "Phalli" in https://www.dictionary.com/browse/phalli.
} 
events and things recieve Penelope's orientation. In fact, the text is a discourse of resurrection and surreptitious return from the in order to "tell [s] her life story in the form of a confession, spinning "a thread of my own" in self-defense and self-justification" (Howells 5). Because of this, Penelope now has access not only to recount the incidents but also to comment on the background of each of her actions, making the readers privy to her thoughts and plans. For example, her most famous trickeries the shroud and the bed - are recalled and explained in greater detail, and others, unnoticed in Homer's version, are for the first time brought to light (Renaux 98). She comments on how she was ordered to thrown into sea (Atwood 2); how she was fetishized a prize for wining a contest (race); how she waited a disgraced woman in her husband's house, and how she was compared to the wicked wife, Clytemnestra, who murders her husband upon his return from Troy.Nowhere is this more evident than in the case of Penelope, Odysseus' long-suffering and faithful wife. She was left behind in Ithaca to fight off the advances of marriage hungry suitors who intend to grab Odysseus' possessions (Atwood 100). In the story of Odysseus, Homer tells of a patient and faithful wife, one who protects the rights of her husband and son. Homer makes it clear: Penelope is the example to follow; Clytemnestra is the example to avoid. So, Penelope is depicted as faithful and domestic woman (Collins 66-7). However, Penelope has problem with ideal portrayal. She is caustic of narrative on Odysseus:

He was always so plausible. Many people have believed thatthis version of events was the true one [...] I knew he wastricky and a liar [...] Hadn't I been faithful? Hadn't I waited, and waited, and waited, despite the temptation [...] And whatdid I amount to, once the official version gained ground? An edifying legend. A stick used to beat other women with. (Atwood 2)

Penelope breaks through the patriarchal fetters that restrain her from going beyond her conventional limits. In regaining her narrative, Penelope dedivinizes the official narrative eulogy on audience. This reverses the power relations that structured the social hierarchies of Greek Society: the enslavement of female servants, the silencing of women, and theglorification of male heroes.

Penelope's narrative mobility also brings revision in conceptualization of the characters and incidents, and also demonstrates acquisition of her agency. For example, Atwood swerves the narrative to deconstruct and rewrite idealized image of Helen in chapter "Helen Ruins My Life." Penelope looks at the events and persons from a subjective distance which gives her an access to what Currie calls "judgmental commentary" on Helen (21). Currie asserts that the voice and narrative 
distance gives a space to look at the incidents and persons with judgments (22-23). Penelope comments on few personal attributes of Helen:

The part of the story she enjoyed the most was the number of men who'd died in the Athenian war: she took their deaths as a tribute to herself. The sad fact is that people had praised her so often and lavished her with so many gifts and adjectives that it had turned her head. She thought she could do anything she wanted, just like the gods from whom - she was convinced - she was descended. (Atwood 75-76)

Penelope wonders “if Helen hadn't been so puffed up with vanity, we might all have been spared the sufferings and sorrows she brought down on our heads by her selfishness and her deranged lust" (Atwood 76). She in an ironic hue questions why she couldn't have led a normal life, and ascribes Helen to any kind of suffering and misfortunes that befell upon her. Whenever Penelope rereads the idealized image of Helen, the reading is interspersed with laughter and sympathy, which can clearly be termed as "sympathetic laughter," in Booth's words, exerted by the narrative distance and subjective liberty Penelope enjoys in this story (12). This retelling on Helen's idealized image shifts the attention. In feminist tradition of writing, this is a "Re-vision- the act of looking back, of seeing with fresh eyes, of entering an old text from a new critical direction ... it is an act of survival"; this is more than an act of creating identity but an act of knowing [ourselves] (Rich 18).

Similarly, the narrative mobility foregrounds the point of view of twelve maids. Themaids, who are indeed hardly more than plot devices in Homer's epic poem, on theother hand, provide a primary focus, as their role and their relevance to Penelope'slife are foregrounded. According to Currie, the mobility of the narrative "effectively determines the position from which the reader views fictional events, creating sympathetic bonds between reader and particular characters by making that position one of intimacy and mental access (27-28). The twelve maids reflect on a variety of issues. For example, the maids imagine: "If I was a princess, with silver and gold / And loved by a hero, / I'd never grow old: / Oh, if a young hero came a-marrying me / I'd always be beautiful, happy, and free!" (Atwood 51). The use of past tense denotes the deprived opportunity and highlights the voiceless plight they underwent: they could not even speak of their desires and wishes. Another subtler narration appears when the maids recounts the birth of Telemachus, who later turns out be the executor of their fate. The narration is ironic:

And the lives of women also are twisted into the strand.

And we, the twelve who were later to die by his hand 


\begin{abstract}
At his father's relentless command,
Sailed as well, in the dark frail boats of ourselves

Through the turbulent seas of our swollen and sore-footed mothers

Who were not royal queens, but a motley and piebald collection,

Bought, traded, captured, kidnapped from serfs and strangers. (Atwood 66)
\end{abstract}

The maids foreshadow their fate while signing on the birth of Telemachus. While they were still talking about the internal matter, they intend to talk more and try to go beyond the inside. This "inside/outside model" of narrative comes up with the deconstructive strategy (Currie 44). While the song that maids sign is the internal form, "its content is often something which is pointed to outside the work," and it brings "external information such as historical,' biographical or referential perspectives to bear" (44).

Atwood celebrates the narratives of the minor characters, and can be termed as what Rosen calls rewriting or "minor character elaborations" that exert rewritings as liberating (143). In Rosen's formulation representations of disenfranchised characters such as women result in their liberation in life, and the investment in the representation of female character, Penelope, or the maids, for instance, is part of what he calls "liberal subjectivism" and "perspectival pluralism" (144). Moreover, this deployment of multiple texts through the voices of twelve maid is the fundamental feature of language, and what Bakhtin calls "Heteroglossia" or dialogic text. (282). This sort of multiple languages at one time produces the multiple contested social voices in a text. The authorial voice is not overpowering and subordinating the voices in the dialogic text but it involves in the dialogic interaction as one of the many voices (Bakhtin 282). Hence, this present text, as a dialogic work embodies dialogic sense of truth by allowing the consciousness of the characters where the characters feel more empowered and having subject position.

TheOdyssey isOdysseus's story. This version does not touch upon the female characters as it speaks of the adventurous and brave incidents of male characters. Homer's narrative choice is shaped by patriarchal exclusions and suppressions (Yurttaş 206). But, in this version, each of the woman character also has a story to tell, though their versions may be different from the original one. In Bakhtin's parlance, it would be"a diversity of social speech types, sometimes even diversity of languages and a diversity of individual voices organized" (262). Therefore, Atwood brings agencies to the character through its metafictional narration. Because of the narrative shift Penelope enjoys more agency and complexity than in most versions or interpretations of Homer's epic poem, 
The Odyssey. Long fascinated by myth and archetype, Atwood is a natural choice to summon Penelope's "true" story by employing a metafictional narrator, and "whose metafictional self-reflexivity (and intertextuality) renders their implicit claims to historical veracity somewhat problematic, to say the least" (Hutcheon 3).

\section{Narrative Self-reflexivity and Intertextual Narration}

The present text cannot be interpreted with in its singularity but "transtextuality, or the textual transcendence of the text," paratextuality and metatextual elements - the way it maintains its title, epigraphs, contents, notes (Genette 1). But, notable narrative reclaim is asserted through the notion of intertextuality. Atwood embarks on the effective presence of The Odyssey in The Penelopiad. In fact, she makes the text as a dynamic site in which relational processes and practices are the focus of analysis instead of static structures and products; consequently, it becomes "an intersection of textual surfaces rather than a point (a fixed meaning), as a dialogue among several writings" (Kristeva 65). This very nature of intertextuality establishes a critical relationship with Homer's text in that it turns out to be a "fiction that is at once metafictional and historical in its echoes of the texts and contexts of the past (Hutcheon 3).

Atwood's revision of The Odyssey is based on the mantra of "incredulity to metanarratives"- disbelief or rejection of any totalizing and holistic view of anything and any postmodern produce is characterized by no grand totalizing master narrative but by smaller and multiple narratives which do not seek (or obtain) any universalizing stabilization or legitimation (Lyotard xxiv). By the same token, this narrative is sceptic of any moral or political judgments because it undermines the validity of any one privileged position or any single truth that comes from Homer's epic. No longer relying upon the validity of metanarratives, it demands alternative possibilities for the construction of alternative truth. One strong example that features the text's intertextuality ${ }^{2}$ appears "Introduction":

Mythic material was originally oral, and also local - a myth would be told in one way in one place and quite differently in another. I have drawn on material other than The Odyssey, especially for the details of Penelope's parentage, her early life and marriage, and the scandalous rumours circulating about her. (Atwood xiv).

\footnotetext{
${ }^{2}$ More evidences of intertextuality are put under "Notes" (Atwood 197) section, in which Atwood alludes to various resources, such as Robert Graves's The Greek Myths, and "Herodotus, Pausanias, Apollodorus, and Hyginus, among many, from which she weaved this story.
} 
Atwood draws upon various for the retelling and de-divinization of divine image of Odysseus. Atwood notes that the most idealized image of him: "he's noted as a persuasive liar and disguise artist - a man who lives by his wits, who devises stratagems and tricks, and who is sometimes too clever for his own good. His divine helper is Pallas Athene, a goddess who admires Odysseus for his ready inventiveness" (1). The Penelopiad does not glorify the acts of The Odyssey. Instead of the male hero Odysseus, The Penelopiad focuses on the female protagonist, and covers not only the events thatform the plot of the Odyssey, but Penelope's entire life story, which takes the form of amemoir. She comments on merit of the character: "While he was pleasuring every nymph and beauty Did he think I would do nothing but my duty? While every girl and goddess he was praising, did he assume I would dry up like raisin?" (Atwood 149).

Retrospection and memory are two seminal strategies that Atwood uses to constitute its intertextuality and self-reflexivity. Deriving the context from Homer's epic and interspersing it memories and feeling of the main performers, Atwood establishes an intertextual but questioning relationship between the current text and the "original" in which "each word (text) is an intersection of other words (texts) where at least one other word (text) can be read" (Kristeva 65). On one occasion, she remembers "When I was quite young my father ordered me to be thrown into the sea. I never knew exactly why, during my lifetime, but now I suspect he'd been told by an oracle that I would weave his shroud" (Atwood 7). She self-reflexively narrates her reminiscences:

I was a kind girl - kinder than Helen, or so I thought. I knew I would have to have something to offer instead of beauty. I was clever, everyone said so - in fact they said it so much that I found it discouraging - but cleverness is a quality a man likes to have in his wife as long as she is some distance away from him." (29)

The twelve maids occupy their agency through various types of intertexts: songs, anthropology lecture, the videotape, drama, performances, and chorus songs. The diversity of the texts eases the maids' exfoliating the pluralized plots of their narratives. The flexibility of genres of texts impart them with freedom to insert themselves in the narrative and have their say. According to Hutcheon, "intertextual parody crosses genre boundaries without reserve" (139), and "replacesthe challenged author-text relationship with one between reader and text,one that situates the locus of textual meaning within the history of discourseitself (126). The chapters of Penelope's tale mixed together withchapters told from the collective perspective of her maids, who were hanged for theirbetrayal at the end of the Odyssey provide two different femaleperspectives, from which the myth is re-told. This shift in narrative 
point of view gives the maids to reflect on their predicament - who they were perceived and were treated, which is not the least part of in the original text. The maids reflect:

We too were children. We too were born to the wrong parents. Poor parents, slave parents, peasant parents, and serf parents; parents who sold us, parents from whom we were stolen ... We were set to work in the palace, as children; we drudged from dawn to dusk, as children . . . W e were told we were dirty. We were dirty. Dirt was our concern, dirt was our business, dirt was our specialty, dirt was our fault . . . All this happened to us when we were children. (Atwood 13-14)

With the intertextuality, Atwood gives a substantial space for the self- reflection of both the narrators - Penelope and the twelve maids. The choice to re-tell the Odyssey from a female perspective by "giv[ing] thetelling of the story to Penelope and to the twelve hanged maids" (xxi) clearly echoes the practice of feminist revision - reclaiming the narrative as perceived by the female protagonist(s). When the narrative point of view changes, the voice also changes, and "meanings in one kind of discourse are overlaid with meanings from another kind of discourse" (Cuddon 454). Again, Penelope confesses: "The two of us were - by our own admission - proficient and shameless liars of long standing. It's a wonder either one of us believed a word the other said. But we did. Or so we told each other" (Atwood 173).

Looked in this light, the novel does not try to "establish Penelope as the new truth, a humanist subject, but to destabilize the epic hero by exposing how the constitution of this male hero depends on the suppression of female sexuality, matriarchal cultures, and an alternative history"(Yurttaş 213). But certainly, this intervention recalls what Gilbert and Gubar termed as "retrieving" the lost and forgotten voice of women in participation in broader social and cultural historicity (75). This trend of revising and reinterpreting Penelope's story ascribes to a feminist revisiting the classical canon that involves "assaulting and revising, deconstructing and reconstructing . . . images inherited from male literature" (Gilbert and Gubar 75). The tendency to "revise" and "deconstructs" the official narration could be ascribed to foregrounding of the marginal voices and characters.

\section{Detecting Discrepancies and Incredulity}

On the surface, the novella may indeed pursue the proclaimed almostdetective-story -like goal of finding the 'real' answers to the questions, "What led to thehanging of the maids, and what was Penelope really up to" (xxi), butany deeper exploration into the world of The Penelopiad will soon problematizes itspremise, and show that these 
questions cannot be answered simply. In strict sense, the present text employs postmodern version of parody that offers "repetition with critical distance that allows ironic signalling of difference at the very heart of similarity" with the Homerian epic; just like in historiographic metafiction this novella "paradoxically enacts both change and cultural continuity" (Hutcheon, "The Politics of Postmodernism" 185). In other words, it parodies and tries to prove the Homeric accounts incongruous by successfully reconstructing the stories of the maids and providing a voice to characters in order to address contradictions overlooked in The Odyssey. On the closer inspection, the novella showcases tremendous amount of parody and irony in order to question the authenticity, reliability and integrity of Homeric accounts, and Atwood interrogates the Homerian perception of Penelope myth and gives a counternarrative on it - a strategy of reclaiming it.

Most of the times, Penelope incisively deconstructs thus contradicts the so-called magniloquent image and reputation of Odysseus. His actions described in Atwood's version ironically depreciate his reputation. This method of Atwood uses as a "rhetorical and structural strategy of resistance and opposition" (Hutcheon "Double Talking" 12). While he was fighting contest to win Penelope for marriage, Penelope's depiction characterizes:

He cheated, as I later learned. My father's brother, Uncle Tyndareus, father of Helen - though, as I've told you, some said that Zeus was her real father - helped him to do it. He mixed the wine of the other contestants with a drug that slowed them down, though not so much as they would notice; to Odysseus he gave a potion that had the opposite effect. (Atwood 35)

Further, Odysseus, the friend of Hermes is featured in such was that anyone who contends him would never win because he learning the craft of cheating and stealing from his grandfather.

This is what Hutcheon would call any art "forms (and its theory) use and abuse, installand then subvert convention in parodic ways, selfconsciously pointingboth to their own inherent paradoxes and provisionality and, of course, totheir critical or ironic re-reading of the art of the past (Historiographic Metafiction 4). "His grandfather Autolycus was well known for these very qualities, and was reputed never to have won anything fairly in his life" (31). Thus, the use of repetition and irony are devices that Atwood uses in order to highlight complications within Odysseus' behavior. When he won the contest as per the tradition and was then expected to stay at the bride's father's palace and contribute his share of male offspring. "He obtained wealth through the marriage - gold cups, silver bowls, horses, robes, weapons, all that trash they used to value so 
much back when I was alive" (Atwood 26). However, Penelope does not term the material possession as gift or something but she is critical of this triumph and call it a "trash because [she] know[s] where most of it ended up. It mouldered away in the ground or it sank to the bottom of the sea, or it got broken or melted down (emphasis is original)" (Atwood 26). In fact, she ridicules this as a "wedding loot" (Atwood 27).

Odysseus' myth of perfect physique was belittled by the maids and by Penelope's glamorous cousin Helen for his short legs (Atwood 9). The maids also show this deformity in his characters and contesting strategies. His image as successful competitor is also parodied as they report "he was able to win the contest and marry her, thanks to a trick perpetrated with the help of Tyndareus, Penelope's uncle and the father of Helen [. . . ] he mixed the wine of the other contestants with a drug that slowed them down, though not so much as they would notice" (Atwood 9).

Penelope narrates her relation with Helen in marked corrosive way and with acute irony, which more exemplified in the chapter entitled "Helen takes a bath." Particularly, in this episode, the two women become sharp and caustic to each other. In Hades, Penelope was walking through the asphodel, Penelope perceives Helen being "followed by her customary horde of male spirits, all of them twittering with anticipation" (153). Helen retorts Penelope that the reason behind large horde is following "Desire does not die with the body ... only the ability to satisfy it" (155). Penelope inculpates Helen of the men's deaths: "So you're washing their blood off your hands'... I hadn't realized you were capable of guilt" (156). And Helen replies with the same acidic tone: "Tell me, little duck - how many men did Odysseus butcher because of you? [...] I am sure you felt more important because of it. Maybe you even felt prettier" (156).

Another incongruity surfaces when Penelope recounts how Helen was perceived in The Odyssey. Penelope's narration on how Helen was treated shed lights on the notion of femininity in as delineated in the Greek story. The sextual attraction and physical beauty was the power that placed Helen always in the center. While she was never summoned by the magicians, "Helen was in much demand" (Atwood 20). "Anyway, the magicians insisted on seeing Helen, and she was willing to oblige. It was like a return to the old days to have a lot of men gawping at her. She liked to appear in one of her Trojan outfits, over- decorated to my taste, but chacun à son goût ${ }^{9}$ " (21). She was fetishized as an attractive object: "All she had to do was bare one of her peerless breasts, and he was down on his knees, and drooling and begging to take her back" (22). Penelope asserts that because of her physical beauty she was never punished even for the fact that she " had driven hundreds of men mad with lust and had caused a great city to go up in flames" (22). 
Moreover, Helen in the text has been described with incisive and slyly funny expressions that have ironic nuances. In Emrmarth's words, writers like Atwood "find in parody a useful tool precisely because the convention denies priority to any single narrative," and they can craft more "pluralized plots and exfoliating styles of postmodern parataxis transcend anything that might be recognized as classical parody and turn into something quite uniquely postmodern" (227). On different occasions, she is described as"the long-necked swan she fancied herself to be" (33); "Helen the septic bitch, root cause of all my misfortunes" (131); "she enjoyed the most was the number of men who'd died in the Athenian war: she took their deaths as a tribute to herself" (73). These ironic quotation, appropriation or intertextuality is another name for parody. These excerpts can be treated as instances of "contesting revision or rereading of the past that both confirms and subverts the power of representations (Hutcheon, The Politics of Postmodernism 91).

Penelope also devotes some parts of the narration to constructing a description of her relationship with the son, Telemachus. Those parts are humorous and - what is particularly important - based on ordinary activities and rooted in everyday experience:

I resolved to have a word with him [Piraeus] later, and speak to his parents about letting him run so wild. Theoclymenus was a stranger. He seemed nice enough, but I made a mental note to find out what could be his ancestry, because boys the age of Telemachus can so easily get into the wrong company. [/] Telemachus wolfed down the food and knocked back the wine, and I reproached myself for not having taught him better table manners. Nobody could say I hadn't tried. (Atwood 129)

Though Telemachus is her son, Penelope revises her perception on him too. In her understanding, he is just like his father- a being constituted by the domineering and deceptive traits. She notes "Not for nothing was he the great-grandson of Autolycus, friend of Hermes the arch-cheat, and the son of wily Odysseus of the soothing voice, fruitful in false invention, persuader of men and deluder of women. Maybe he had some brains after all (133). When she asked about Helen, Telemachus reported to her mother falsely. At that time also she knows that "Telemachus was in on the deception: I could see that as well. He was by nature a spinner of falsehoods like his father, but he was not yet very good at it (135). These "parodic and ironic representational strategies have offered feminist artists an effective way of working within and yet challenging dominant patriarchal metanarrative discourses" (Hutcheon, Incredulity toward Metanarratives 43).

Hutcheon argues that "to parody is not to destroy the past [but] to enshrine the past and to question it (The Canadian Postmodern 126). The 
text exhibits comic and parodying taste. The Penelopiad's pivotal maids, serve as an accusatory Greek chorus and also as barbed comic relief. In Hades - where people are now free to speak what they think in a way they weren't free in life, they've finally gained the voices that Homer denied them. The narrators always know too much about the inconsistencies and what is hidden in the original epic. This knowledge of "too much" brings ironic implications on the surfaces.

\section{Conclusion}

While demystifying the Penelope myth, Atwood blurs the archetype of Greek mythology enriching the novella with the acute sense of characterization of marginal characters. In other words, this novella not only fills the void left by the classical Greek myth on Penelope by Homer and at the same time points out the incongruities. Atwood interweaves the texture of the Homerian myth on Penelope in several ways and knits the form of narration in a differing direction. She, in this reworking of The Penelopiad, subverts the orthodox version of the Greek myth in postmodern historiographic fashion. Most of mythic materials are originally oral, and also local. However, regarding this text at least, Atwood contends that a myth transmitted in one way in one particular place can be told quite differently in another time and another place. Penelope aims to show with her story that truth can be found exclusively neither in the mythical tales nor in the various subjective points of view, but only in a position that is in-between the two, and moreover, that this same "truth" can vary according to the time in which the story is told. What was valid two thousand years ago cannot still be valid in our day.

In short, Penelope, often deemed to be the quintessential faithful wife, goes from being the object of a masculine narrative to becoming the subject of her own story. Atwood's retelling shifts the perspective from Penelope to the Chorus that personifies the voices of the maids. This shift in perspective has the effect of looking with new eyes not only at the figure of Penelope but also, more generally, at all the other mythical characters. Though the Penelope of The Penelopiad may not wholly and radically intend to subvert the events narrated in the Homeric poem, it reveals the other side of the docility and passivity. While doing so, Atwood advocates for the silenced characters and their strong subjective responses.

\section{Works Cited}

Abate-Çelebi, Barbara Dell. Penelope's Daughters. Zea Books, 2016. Akgün, Buket. "The Penelopiad: Dislodging the Myth of Penelope as the

Archetype of Faithful and Patient Wife."4th Internal IDEA Studies in English, Celal Bayar University, April 2010, 36-42. 
Atwood Margaret. The Penelopiad. Conongate Book, 2005.

Badley, Linda. "The Aesthetics of Postmodern Parody: An Extended Definition." The Comparatist, vol. 7, 1983, pp. 36-47. JSTOR, www.jstor.org/stable/44366698. Accessed 18 June 2020.

Bakhtin, M.M. The Dialogic Imagination: Four Essays by M.M. Bakhtin. Trans. Caryl Emerson and Michael Holquist. Ed. Michael Holquist, University of Texas Press, 1981.

Booth, Wayne C. The Rhetoric of Fiction. University of Chicago Press, 2010.

Collins, Shannon Carpenter. "Setting the Stories Straight: A Reading of Margaret Atwood's The Penelopiad." Carson-Newman Studies, vol. 11, 2006, pp. 57-66.

Cuddon, John Anthony. The Penguin Dictionary of Literary Terms and Literary Theory. Penguin Beds Group, 1992.

Currie, Mark. Postmodern Narrative Theory. Macmillan International Higher Education, 2010.

Ermarth, Elizabeth Deeds. "Finger exercises: Parody as a practice for postmodernity." European Journal of English Studies, vol. 3, no.2, 1999, pp. 226-240.

Genette, Gärard. Palimpsests: Literature in the second degree. vol. 8, U of Nebraska Press, 1997.

Gilbert, Sandra M., and Susan Gubar. The madwoman in the attic: The woman writer and the nineteenth-century literary imagination. Veritas Paperbacks, 2020.

Hauser, Emily. "'There is another story': writing after the Odyssey in Margaret Atwood's The Penelopiad." Classical Receptions Journal, vol.10, no.2, 2018, pp. 109-126.

Homer. The Odyssey. Trans. Robert Fagales. Punguin, 1997.

Howells, Coral Ann. "Five Ways of Looking at The Penelopiad." Sydney Studies in English 32 (2008).

Howells, Coral Ann. 'We can't help but be modern': The

Penelopiad." Once upon a time: myth, fairy tales and legends in

Margaret Atwood's writings (2008): 57-72.

Hutcheon, Linda. "Historiographic Metafiction Parody and the Intertextuality of History.” Johns Hopkins University, 1989.

---. "Incredulity toward Metanarrative: Negotiating Postmodernism and Feminisms." Tessera (1989), pp. 39-44.

---. Hutcheon, Linda. "The Politics of Postmodernism: Parody and History." Cultural Critique, no. 5, 1986, pp. 179-207. JSTOR, www.jstor.org/stable/1354361. Accessed 29 June 2020.

---. Double talking: Essays on verbal and visual ironies in Contemporary Canadian art and literature. Ecw Press, 1992. 
---. The Canadian postmodern: a study of contemporary EnglishCanadian fiction. Oxford University Press, 1988.

Jung, Susanne. "“A Chorus Line': Margaret Atwood's Penelopiad at the Crossroads of Narrative, Poetic and Dramatic Genres." Connotations: A Journal for Critical Debate 24.1 (2014): 41-62.

Kapuscinski, Kiley. "Ways of Sentencing: Female Violence and Narrative Justice in Margaret Atwood's The Penelopiad." Essex Human Rights Review 4.2 (2007).

Knox, Bernard. "Introduction to Homer."The Odyssey. Translated by Robert Fagles, Penguin House, 1996: 13-86.

Kristeva, Julia. "Word, Dialogue, and Novel."Desire and Language: A Semiotic Approach to Literature and Art (1980).

Lyotard, Jean-François. The Postmodern Condition: A Report on Knowledge. Vol. 10. University of Minnesota Press, 1984.

Renaux, Sigrid. "Margaret Atwood and the Re-invention of Myth in The Penelopiad." Interfaces Brasil/Canadá 11.1 (2011): 67-96.

Rich, Adrienne. "When We Dead Awaken: Writing as Re-Vision." College English, vol. 34, no. 1, 1972, pp. 18-30. JSTOR, www.jstor.org/stable/375215. Accessed 2 July 2020.

Rosen, Jeremy M. "Minor Characters Have Their Day: The Imaginary and Actual Politics of a Contemporary Genre." Contemporary Literature 54.1 (2013): 139-174.

Worton, Michael, and Judith Still, eds. Intertextuality: Theories and Practices. Manchester University Press, 1991.

Yurttaş, Hatice. "Reading The Penelopiad through Irigaray: Rewriting Female Subjectivity." Journal of Faculty of Letters/Edebiyat Fakultesi Dergisi 34.1 (2017). 